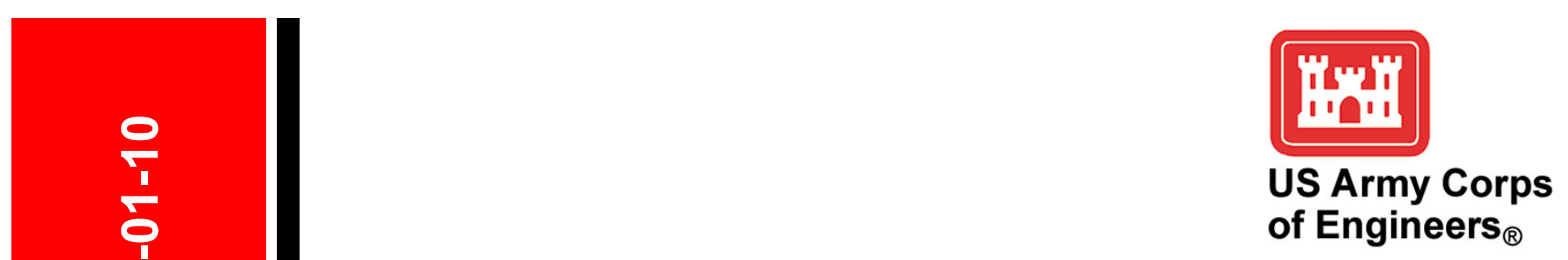

Installation Restoration Research Program

Base-Induced 2,4,6-Trinitrotoluene Transformation, Titration Studies

Lance D. Hansen, David D. Ringelberg, Deborah R. Felt, and Jeffrey D. Davis

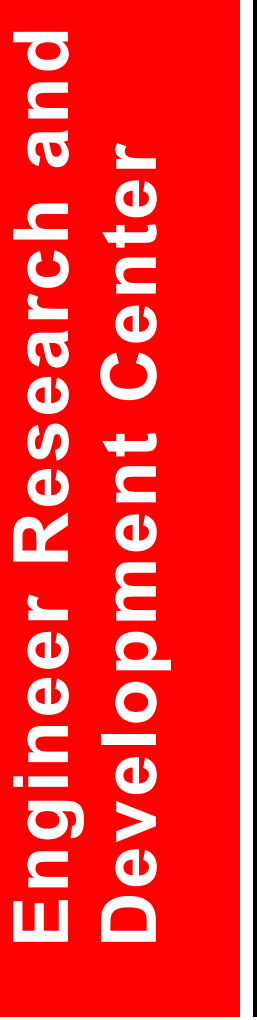


The contents of this report are not to be used for advertising, publication, or promotional purposes. Citation of trade names does not constitute an official endorsement or approval of the use of such commercial products.

The findings of this report are not to be construed as an official Department of the Army position, unless so designated by other authorized documents. 


\section{Base-Induced 2,4,6-Trinitrotoluene Transformation, Titration Studies}

by Lance D. Hansen, Jeffrey D. Davis

Environmental Laboratory

U.S. Army Engineer Research and Development Center 3909 Halls Ferry Road

Vicksburg, MS 39180-6199

David D. Ringelberg

Cold Regions Research and Engineering Laboratory

U.S. Army Engineer Research and Development Center

72 Lyme Road

Hanover, NH $\quad 03755-1290$

Deborah R. Felt

Applied Research Associates, Inc., Southern Division

112 Monument Place

Vicksburg, MS 39180

Final report

Approved for public release; distribution is unlimited 


\section{Contents}

Preface $\mathrm{V}$

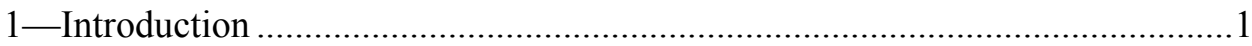

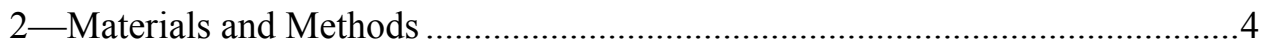

Chemistry and Toxicology of the OH/TNT Reaction...................................

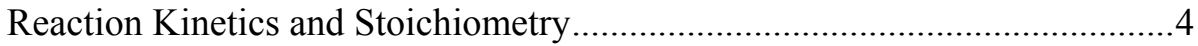

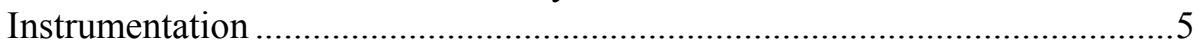

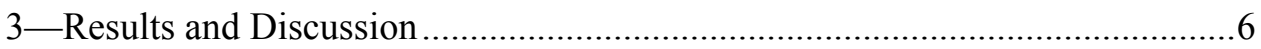

Chemistry and Toxicology of the OH/TNT Reaction Products......................6

Reaction Kinetics and Stoichiometry ....................................................... 9

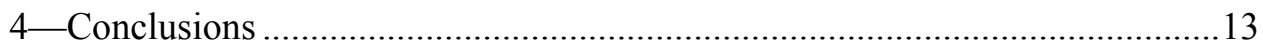

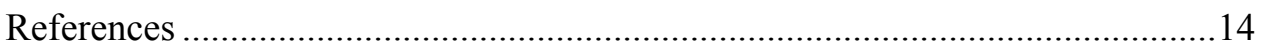

SF 298

\section{List of Figures}

Figure 1. TNT transformation product formation and disappearance ...............6

Figure 2. UV spectra of unidentified intermediates .......................................

Figure 3. Acute toxicity of TNT solutions challenged with $\mathrm{NaOH}$.................8

Figure 4. TNT Concentrations in various $\mathrm{pH}$ buffer solutions as a function

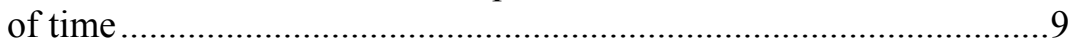

Figure 5. Titration curves of various buffered TNT solutions ........................10

Figure 6. Parametric analysis of TNT removal model ..................................12 


\section{List of Tables}

Table 1. Buffer Composition ………..........................................................

Table 2. HPLC retention times for TNT and unknown intermediates .............. 8

Table 3. Regression analysis of titration curves of TNT ............................11 


\section{Preface}

The work reported herein was conducted at the U.S. Army Engineer Research and Development Center (ERDC), Vicksburg, MS, as part of cleanup technology development supported by the Environmental Quality Technology Program, Project AF25-302E.

This report was prepared by Mr. Lance Hansen of the Environmental Engineering Branch (EEB), Environmental Laboratory (EL), ERDC; Mr. David Ringelberg of the Environemental Sciences Branch of the Cold Regions Research and Engineering Laboratory (CRREL), ERDC; Ms. Deborah Felt of Applied Research Associates, Inc. (Southern Division), and Dr. Jeffrey Davis of the Environmental Engineering Branch (EEB), EL, ERDC. Chemical analyses were performed by the Environmental Chemistry Branch, EL, ERDC.

We gratefully acknowledge the support provided by Dr. John Cullinane, EL, ERDC. The study was conducted under the direct supervision of Mr. Danny Averett, Chief, EEB, and Dr. Richard E. Price, Chief, Environmental Processes and Engineering Division, and under the general supervision of Dr. Edwin A. Theriot, Acting Director, EL.

At the time of publication of this report, Director of ERDC was Dr. James R. Houston, and COL John W. Morris III, EN, was Commander and Executive Director of ERDC.

This report should be cited as follows:

Hansen, L. D., Ringelberg, D. D., Felt, D. R., and Davis, J. D. (2001). "Base-induced 2,4,6-trinitrotoluene transformation, titration studies," ERDC TR-01-10, U.S. Army Engineer Research and Development Center, Vicksburg, MS.

The contents of this report are not to be used for advertising, publication, or promotional purposes. Citation of trade names does not constitute an official endorsement or approval of the use of such commercial products. 


\section{Introduction}

The explosive 2,4,6-trinitrotoluene (TNT), as an environmental contaminant, is largely the result of munitions manufacturing. As of 1985, 2 million pounds per year of TNT was being produced in the United States (Harter 1985). Tsia (1991) reported that during both world wars, TNT was produced in enormous quantities, generating an average of 80,000 gal of explosives-contaminated water and 250,000 lb of solid waste per day. Although TNT production in the United States has since been drastically reduced, environmental TNT contamination remains a significant problem (Heilman,Wiesmann, and Stenson 1996). During loading, transporting, and handling, TNT was spilled, dumped, or otherwise released into the environment in large quantities. These incidents have resulted in contaminant concentrations as large as $10,000 \mathrm{ppm}$ in soil and $100 \mathrm{ppm}$ in water (Fernando, Bumpus, and Aust 1990). Additionally, cleaning and repacking of old munitions continues to generate large continuous flows of TNTcontaminated industrial wastewater (Boopathy et al. 1994).

The U.S. Environmental Protection Agency (EPA) lists TNT as a priority pollutant and has recommended its removal from contaminated sites. It has been advised that the maximum allowable TNT concentration in drinking water be set at $140 \mu \mathrm{g} / \mathrm{L}$. The EPA lifetime health advisory for TNT in drinking water is $20 \mu \mathrm{g} / \mathrm{L}$ (Rosenblatt et al.1991, Roberts and Hartley 1992). TNT may have a significant detrimental impact on the environment because of its toxicity towards algae, invertebrates, and fish (Won, DiSalvo, and Ng 1976, Bradley and Chapelle 1995) and the growth inhibition seen in fungi, bacteria, and plants (Bradley and Chapelle 1995, Spiker, Crawford, and Crawford 1992, Palazzo and Leggett 1986, Simini et al. 1995).

Won, DiSalvo, and $\mathrm{Ng}$ (1976) studied the effects of TNT on unicellular green algae, tidepool copepods, oyster larvae, and Salmonella typhimurium. They found that TNT and several of its metabolites in concentrations as low as $2.5 \mathrm{ppm}$ caused some ill effects, and concentrations as low as $5 \mathrm{ppm}$ were toxic and/or mutagenic. White rot fungus has been known to degrade TNT by its nonspecific extracellular peroxidases, but TNT is toxic to this organism above 24 ppm in the soil (Spiker, Crawford, and Crawford 1992). Bacterial consortia that had not been previously exposed to TNT showed toxic effects at TNT concentrations as low as $0.23 \mathrm{ppm}$. Bacterial consortia isolated from contaminated sites showed up to 11 percent mineralization of TNT in concentrations up to $113 \mathrm{ppm}$, but TNT was toxic to the consortia at concentrations above that level. 
Toxicity studies have also indicated that TNT has adverse effects on humans and laboratory test animals. TNT and its metabolites are considered to be both mutagenic and carcinogenic, Class C (Rosenblatt et al. 1991, ASTDR 1995, Jarvis, McFarland, and Honeycutt 1998).

The study of TNT degradation has interested researchers for many decades. Since the mid-1970s, beginning with McCormick, Feeherry, and Levinson (1976), biotransformation of TNT has been of significant interest. Since then, many researchers have attempted to evaluate various mechanisms of TNT biodegradation and optimize TNT biodegradation under various conditions of nutrient and substrate amendment, $\mathrm{pH}$ control, $6 \mathrm{~h}$ control, bioaugmentation, and surfactant addition. Experimental results have varied drastically. Consequently, bioremediation of TNT-contaminated soil, sediments, and water is still considered innovative and is not widely accepted by regulatory officials overseeing the cleanup of explosives-contaminated sites.

More recently it has been recognized that abiotic reduction may provide mechanisms to transform not only parent contaminants, but also toxic products generated by reductive transformation of the parent compound. An abiotic reduction of organic pollutants in reducing environments has drawn considerable attention.

The transformation of TNT in basic solutions has long been established. Urbanski (1964) described a reddish brown solution after the addition of base, but no products or mechanisms were identified. Saupe, Garvnes, and Heinze (1997) conducted ex situ flask experiments with high alkaline attack (pH 14), resulting in complete TNT transformation and partial mineralization. The intent of this work was to follow chemical pretreatment with thermal treatment for destroying residual byproducts. Saupe suggested that alkaline hydrolysis may be an effective treatment when coupled with another technology (e.g. biological remediation).

Several technologies for TNT degradation were enhanced at elevated $\mathrm{pH}$. Dillert et al. (1995) noted that at $\mathrm{pH} 11$, the rate of TNT transformation with ultraviolet light was as fast as if a $\mathrm{TiO}_{2}$ catalyst were present. Brannon, Price, and Hayes (1998) reported that at $\mathrm{pH} 8$, the TNT transformed faster than at $\mathrm{pH} 6$ or 7 when exposed to Fe(II). TNT degradation by a combination of UV light, ozone, and electrohydraulic discharge was enhanced at and above $\mathrm{pH} 5$ (Lang et al. 1998). Degradation intermediates of TNT were polymerized in alkaline conditions during anaerobic bioremediation of soils (Funk et al. 1993). Dunnivant and Schwarzenbach (1992) reported that TNT degradation caused by natural organic matter was increased at elevated $\mathrm{pH}$.

Saupe, Garvnes, and Heinze (1997) studied the alkaline hydrolysis of TNT at elevated temperatures. Adding sodium hydroxide to TNT solutions created a dark brown hydrosylate. Above $60{ }^{\circ} \mathrm{C}$, polymerization was evident, with increased molecular size in the dissolved organic fraction. Solids were formed instead of mineralization at and above $200{ }^{\circ} \mathrm{C}$ with this method. A Meisenheimer or charge transfer complex was postulated. The authors suggested a treatment of 
$80{ }^{\circ} \mathrm{C}$ with sodium hydroxide, followed by a biotreatment technology after neutralization.

Arienzo (1999) found that TNT was completely removed from soil in $10 \mathrm{~min}$ with the application of 1 percent calcium hydroxide, $\mathrm{Ca}(\mathrm{OH})_{2}$. In a recent study, Emmrich $(1999,2001)$ also treated TNT solutions and TNT-contaminated soils with calcium hydroxide at $20^{\circ} \mathrm{C}$. Aqueous samples were extracted with ethyl acetate, brought to dryness, dissolved in methanol, and analyzed for TNT by gas chromatography. Nitrite and nitrate formation were also reported. TNT transformation was described by a psuedo-first-order rate constant with respect to TNT. An initial violet color was interpreted as the formation of a TNT anion.

A closer examination of the alkaline hydrolysis of TNT is required before this technology is ready to use for remediating contaminated soils or water. This paper describes a study of the chemical and toxicological effects of increased $\mathrm{pH}$ on TNT-contaminated water. This research also provided insight into the kinetics and stoichiometry of the hydrolytic reaction. 


\section{Materials and Methods}

\section{Chemistry and Toxicology of the OH/TNT Reaction}

A $100-\mathrm{mL}$ TNT solution $(86.8 \mathrm{mg} / \mathrm{L})$ was titrated with $2-\mathrm{mL}$ aliquots of $1-\mathrm{M}$ $\mathrm{KOH}$ over a pre-determined time course $(1,5,15$, and $30 \mathrm{~min}, 1,3,5,7,22,30$, and $48 \mathrm{hr}$ ). Immediately following each titration event, 2-mL aqueous samples were collected and analyzed for TNT using a modified EPA method 8330. The $\mathrm{pH}$ was recorded (after three-point calibration) following each titration event during sample collection.

The toxic effect of hydroxide treatment was determined by adding sodium hydroxide to water contaminated with TNT at $10 \mathrm{mg} / \mathrm{L}$ and $100 \mathrm{mg} / \mathrm{L}$. Sodium hydroxide was added to $2 \mathrm{mM}$ and $4 \mathrm{mM}$ in each TNT solution. Acute toxicity was determined for the untreated solution and each treated solution according to the standard Microtox ${ }^{\circledR}$ procedure, Microtox ${ }^{\circledR}$ Acute Toxicity (Condensed) 3 Samples Simultaneously Test protocol, 1995 (Azur Environmental). The results are reported as $\mathrm{EC}_{50}$ values, the effective concentration where 50 percent of the expected fluorescence from the test bacterium, Vibrio fischeri, is inhibited. Higher $\mathrm{EC}_{50}$ values indicate lower acute toxicity.

\section{Reaction Kinetics and Stoichiometry}

To evaluate the effect of time on the hydrolytic reaction of TNT, several buffers were made; their composition is shown in Table 1. Twenty milliliters of each buffer was added to flasks containing $80 \mathrm{~mL}$ of $21.5-\mathrm{mg} / \mathrm{L}$ TNT solution. After incubating for $1 \mathrm{~min}$ and $24 \mathrm{hr}$, aliquots of the buffered solution were taken and neutralized with $0.1-\mathrm{N} \mathrm{HCl}$. Samples were analyzed immediately for TNT concentration.

To determine the $\mathrm{pH}$ required to remove TNT, four of the buffers shown in Table 1 (pH levels 7, 8, 9, and 10) were inoculated with TNT to $24 \mathrm{mg} / \mathrm{L}$ in triplicate. These solutions were titrated at 1-min intervals by adding $1 \mathrm{~mL}$ of $0.1-\mathrm{N} \mathrm{NaOH}$, stirring the solution for $1 \mathrm{~min}$, and removing and neutralizing a 1-mL aliquot for TNT analysis. 


\begin{tabular}{|c|c|}
\hline $\begin{array}{l}\text { Initial pH } \\
\text { Value }\end{array}$ & Buffer Composition \\
\hline 7 & $50 \mathrm{~mL}$ 0.1-M KH${ }_{2} \mathrm{PO}_{4}, 29.1 \mathrm{~mL}$ 0.1-N NaOH, $20.9 \mathrm{~mL} \mathrm{H}{ }_{2} \mathrm{O}$ \\
\hline 8 & $50 \mathrm{~mL}$ 0.1-M KH${ }_{2} \mathrm{PO}_{4}, 46.7 \mathrm{~mL} 0.1-\mathrm{N} \mathrm{NaOH}, 3.3 \mathrm{~mL} \mathrm{H} \mathrm{H}_{2} \mathrm{O}$ \\
\hline 9 & $50 \mathrm{~mL}$ of $0.1-\mathrm{M} \mathrm{H}_{3} \mathrm{BO}_{3}, 20.8 \mathrm{~mL} 0.1-\mathrm{N} \mathrm{NaOH}, 29.2 \mathrm{~mL} \mathrm{H} \mathrm{H}_{2}$ \\
\hline 10 & $50 \mathrm{~mL} \mathrm{NaHCO} 3,10.7 \mathrm{~mL}$ 0.1-N NaOH, $39.3 \mathrm{~mL} \mathrm{H} \mathrm{H}_{2} \mathrm{O}$ \\
\hline 11 & $50 \mathrm{~mL}$ 0.05-M NaHCO $3,22.7 \mathrm{~mL} 0.1-\mathrm{N} \mathrm{NaOH}, 27.3 \mathrm{~mL} \mathrm{H} \mathrm{H}_{2} \mathrm{O}$ \\
\hline
\end{tabular}

\section{Instrumentation}

Explosives analysis was performed using a Hewlett Packard 1090 with diode array detector (DAD) at $254 \mathrm{~nm}$. A C-18 reverse-phase column and an isocratic mobile phase of $68 \%$ methanol/ butanol mixture (98:2) and 34\% 20-mM ammonium chloride solution were used. 


\section{Results and Discussion}

\section{Chemistry and Toxicology of the OH/TNT Reaction Products}

The complete removal of TNT $(86.6 \mathrm{mg} / \mathrm{L})$ occurred within $1 \mathrm{~min}$ after titration with $2 \mathrm{~mL}$ of $1-\mathrm{N} \mathrm{NaOH}$. The $\mathrm{pH}$ level of the solution was measured after each addition. The $\mathrm{pH}$ level increased from an initial value of 6 to a value of 12 after $1 \mathrm{~min}$, and this $\mathrm{pH}$ value was then sustained throughout the experiment. Several unidentified products were produced after continued titration; their production and disappearance are shown in Figure 1. The spectra of these transformation products are shown in Figure 2.

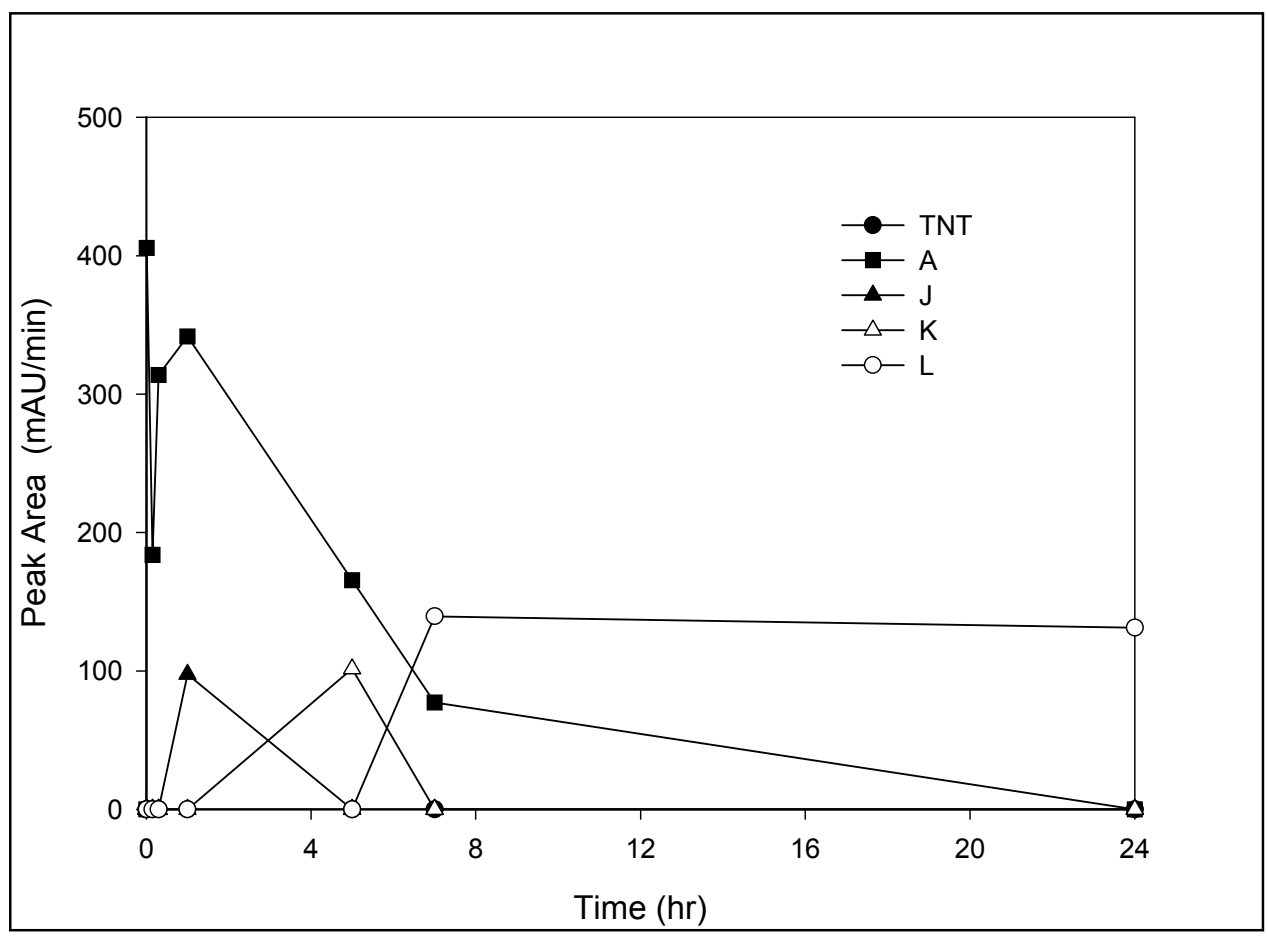

Figure 1. TNT transformation product formation and disappearance 


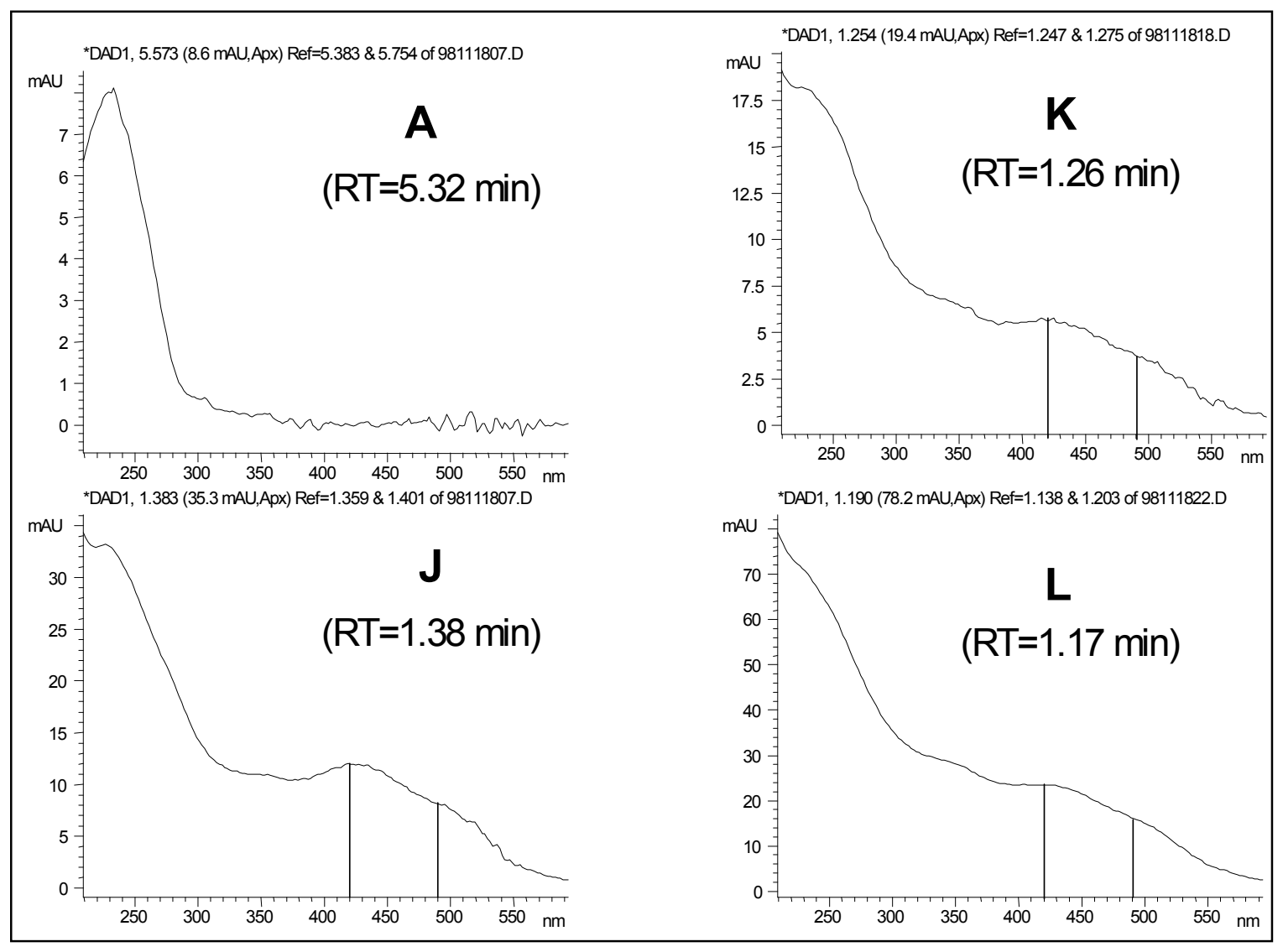

Figure 2. UV spectra of unidentified intermediates

A closer examination of Figure 1 reveals a succession of the unknown intermediates schematically represented by:

$$
\mathrm{TNT} \rightarrow \mathrm{A} \rightarrow \mathrm{J} \rightarrow \mathrm{K} \rightarrow \mathrm{L}
$$

Table 2 shows the retention times for TNT and the unknown compounds. The reverse-phase column was used in the HPLC for separating compounds. Shorter retention times indicate increasingly polar compounds. The sequence shown above for the production and disappearance of TNT and unknown products, and the results summarized in Table 2, indicate that the reaction of hydroxide and TNT causes an increase in polarity. Studies are underway to identify these unknown compounds. 


\section{Table 2 \\ HPLC Retention Times for TNT and Unknown Intermediates}

\begin{tabular}{||l|l||}
\hline Compound & HPLC Retention Time (min) \\
\hline \hline TNT & 5.94 \\
\hline Unknown compound A & 5.32 \\
\hline Unknown compound J & 1.38 \\
\hline Unknown compound K & 1.26 \\
\hline Unknown compound L & 1.17 \\
\hline
\end{tabular}

Although TNT can demonstrably be removed from aqueous solutions by elevating the $\mathrm{pH}$, it remained to be determined if the addition of base decreased TNT's toxicity. Figure 3 is a plot of the acute toxicity of two solutions $(10 \mathrm{mg} / \mathrm{L}$ and $100 \mathrm{mg} / \mathrm{L}$ ) of TNT after the addition of $\mathrm{NaOH}$ at concentrations of 0,2 , and 4-mM NaOH and an incubation period of $1 \mathrm{hr}$. The addition of $\mathrm{NaOH}$ decreased the toxicity of TNT at concentrations of 10 and $100 \mathrm{mg} / \mathrm{L}$. These results show that the addition of hydroxide to TNT solutions is a rapid method for both removing TNT from solution and reducing the toxicity in that solution.

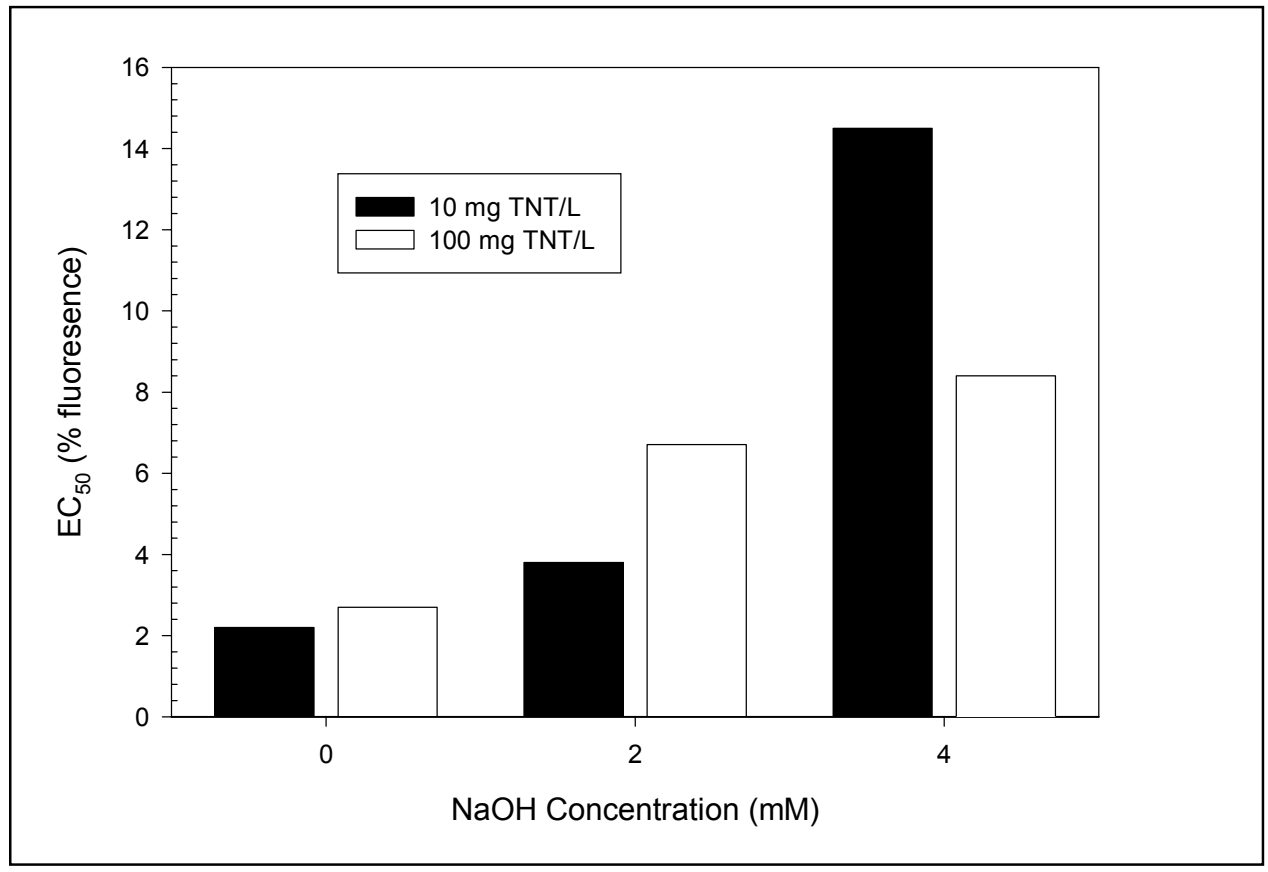

Figure 3. Acute toxicity of TNT solutions treated with $\mathrm{NaOH}$ 


\section{Reaction Kinetics and Stoichiometry}

The reaction kinetics of TNT and $\mathrm{NaOH}$ were determined in a set of experiments conducted to examine the effect of $\mathrm{pH}$ and time on the removal of TNT from water. TNT was added to five buffered solutions of various $\mathrm{pH}$ values, and aliquots were removed after $1 \mathrm{~min}$ and $24 \mathrm{hr}$ and examined for TNT concentration. The results of this experiment, as shown in Figure 4, indicate no significant difference between the samples removed after $1 \mathrm{~min}$ and $24 \mathrm{hr}(\mathrm{p}=0.05)$. The results for effect of $\mathrm{pH}$ showed a small removal (36\%) of TNT at $\mathrm{pH} 11$, indicating a very rapid removal of TNT at elevated $\mathrm{pH}$.

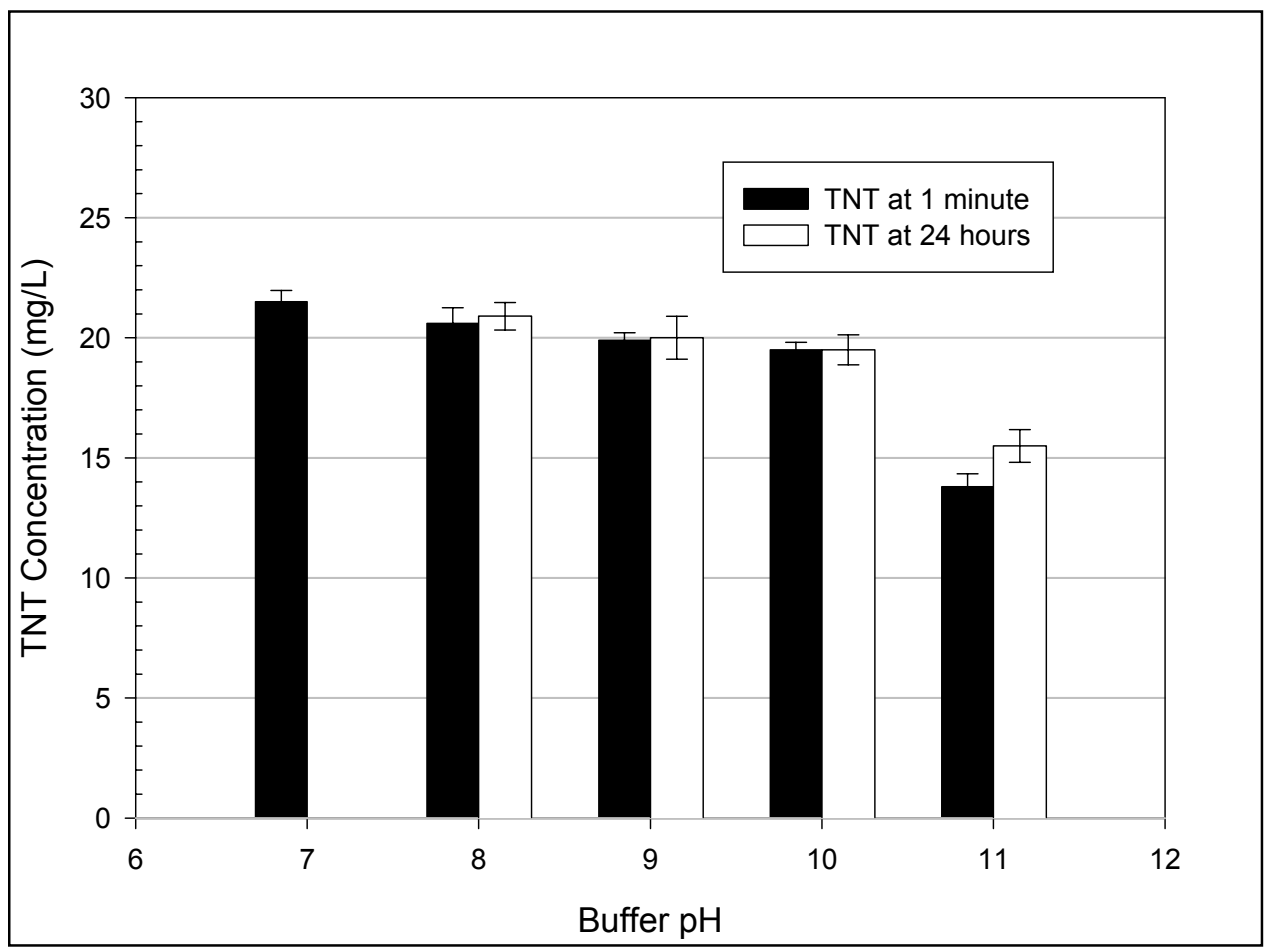

Figure 4. TNT concentrations in buffer solutions of various $\mathrm{pH}$ values as a function of time

Titrations were performed to examine the pronounced effects of $\mathrm{pH}$ on the removal of TNT from solution. The titrations were carried out in triplicate in buffered solutions at pHs of 7, 8, 9, and 10. The results of these titrations (Figure 5) follow similar patterns. Little or no removal of TNT was found at pHs below 10, and complete removal was found at pHs above 11.5. 


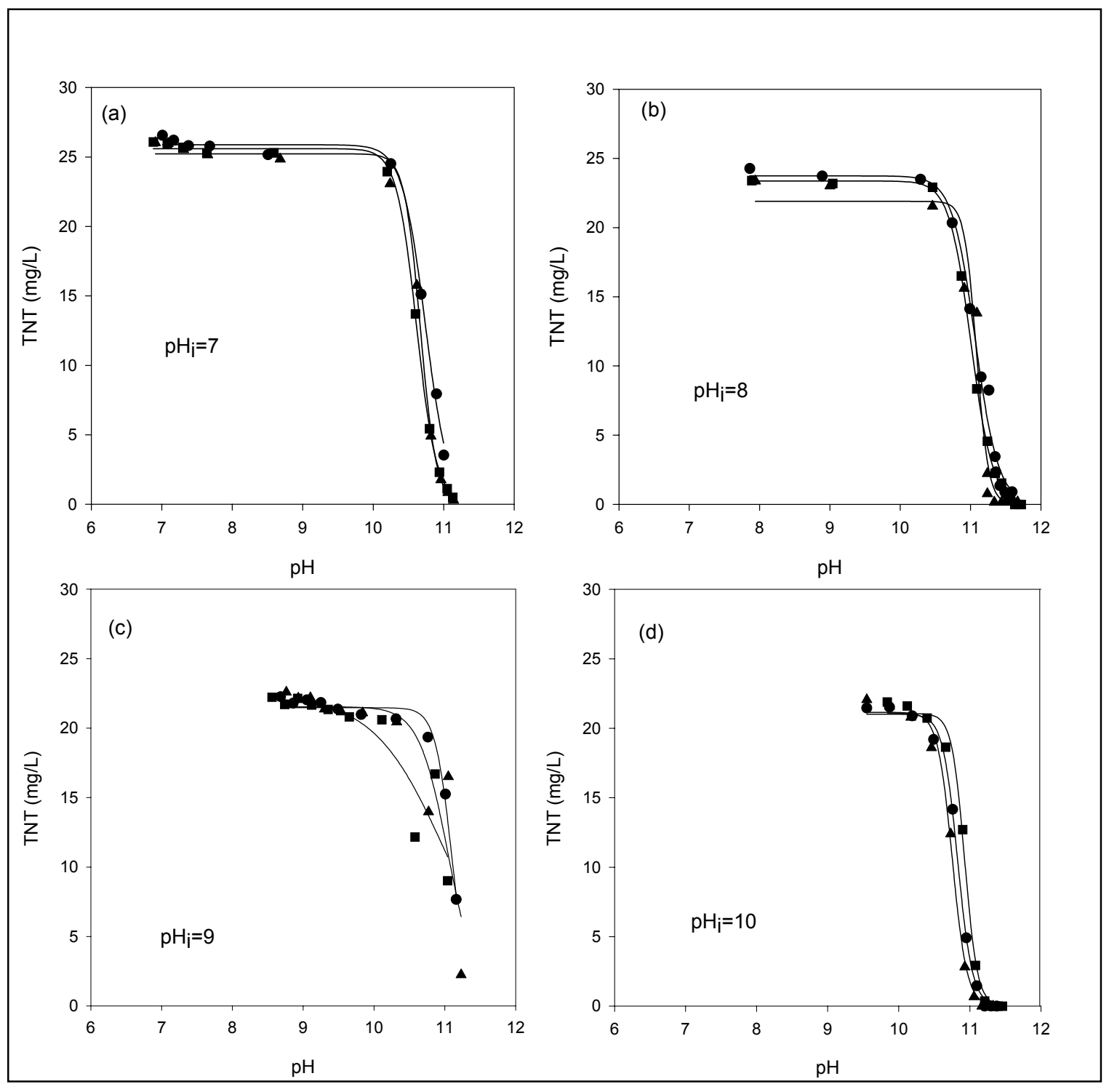

Figure 5. Titration curves of various buffered TNT solutions

Using a sigmoid function, a curve was fit to the data obtained from the titrations (Figure 5). The sigmoid function used is

$$
C=\frac{C_{0}}{1+\exp \left[\frac{p H-p H_{1 / 2}}{b}\right]}
$$


where

$C_{0} \quad=$ initial TNT concentration $(\mathrm{ppm})$

$p H_{1 / 2}=\mathrm{pH}$ at $50 \% \mathrm{TNT}$ removal

$b \quad=$ empirical constant

The results of a regression analysis of the titration curves from Figure 5 are summarized in Table 3 . This analysis yields a $\mathrm{pH}_{1 / 2}$ of $10.9 \pm 0.18$, with an empirical coefficient of $0.16 \pm 0.11$. The large standard deviation associated with the empirical coefficient caused concern. A parametric analysis was performed to examine the sensitivity of this empirical coefficient. The results are show in Figure 6. A cursory examination of Figure 6 shows that over the range of values for $b(0.086$ to 0.502$)$, little difference was found. Therefore this parameter is insensitive.

\begin{tabular}{|c|c|c|c|c|}
\hline \multicolumn{5}{|c|}{$\begin{array}{l}\text { Table } 3 \\
\text { Regression Analysis of Titration Curves of TNT }\end{array}$} \\
\hline & $C_{0}(p p m)$ & $\mathrm{pH}_{1 / 2}$ & b & $r^{2}$ \\
\hline \multicolumn{5}{|l|}{$\mathrm{pH}_{\mathrm{i}}=7$} \\
\hline A & 25.9 & 10.7 & 0.164 & 0.996 \\
\hline B & 25.6 & 10.6 & 0.142 & 0.999 \\
\hline C & 25.2 & 10.7 & 0.113 & 0.977 \\
\hline \multicolumn{5}{|l|}{$\mathrm{pH}_{\mathrm{i}}=8$} \\
\hline A & 23.7 & 11.1 & 0.164 & 0.990 \\
\hline B & 23.4 & 11.0 & 0.154 & 0.999 \\
\hline C & 21.9 & 11.1 & 0.086 & 0.971 \\
\hline \multicolumn{5}{|l|}{$\mathrm{pH}_{\mathrm{i}}=9$} \\
\hline A & 21.5 & 11.1 & 0.118 & 0.981 \\
\hline B & 22.3 & 11.0 & 0.502 & 0.833 \\
\hline C & 21.5 & 11.1 & 0.208 & 0.827 \\
\hline \multicolumn{5}{|l|}{$\mathrm{pH}_{\mathrm{i}}=10$} \\
\hline A & 21.0 & 10.8 & 0.104 & 0.998 \\
\hline B & 21.1 & 10.9 & 0.090 & 0.996 \\
\hline C & 21.1 & 10.8 & 0.103 & 0.996 \\
\hline Mean & 22.85 & 10.9 & 0.16 & \\
\hline $\begin{array}{l}\text { Standard } \\
\text { Deviation }\end{array}$ & 1.85 & 0.18 & 0.11 & \\
\hline
\end{tabular}




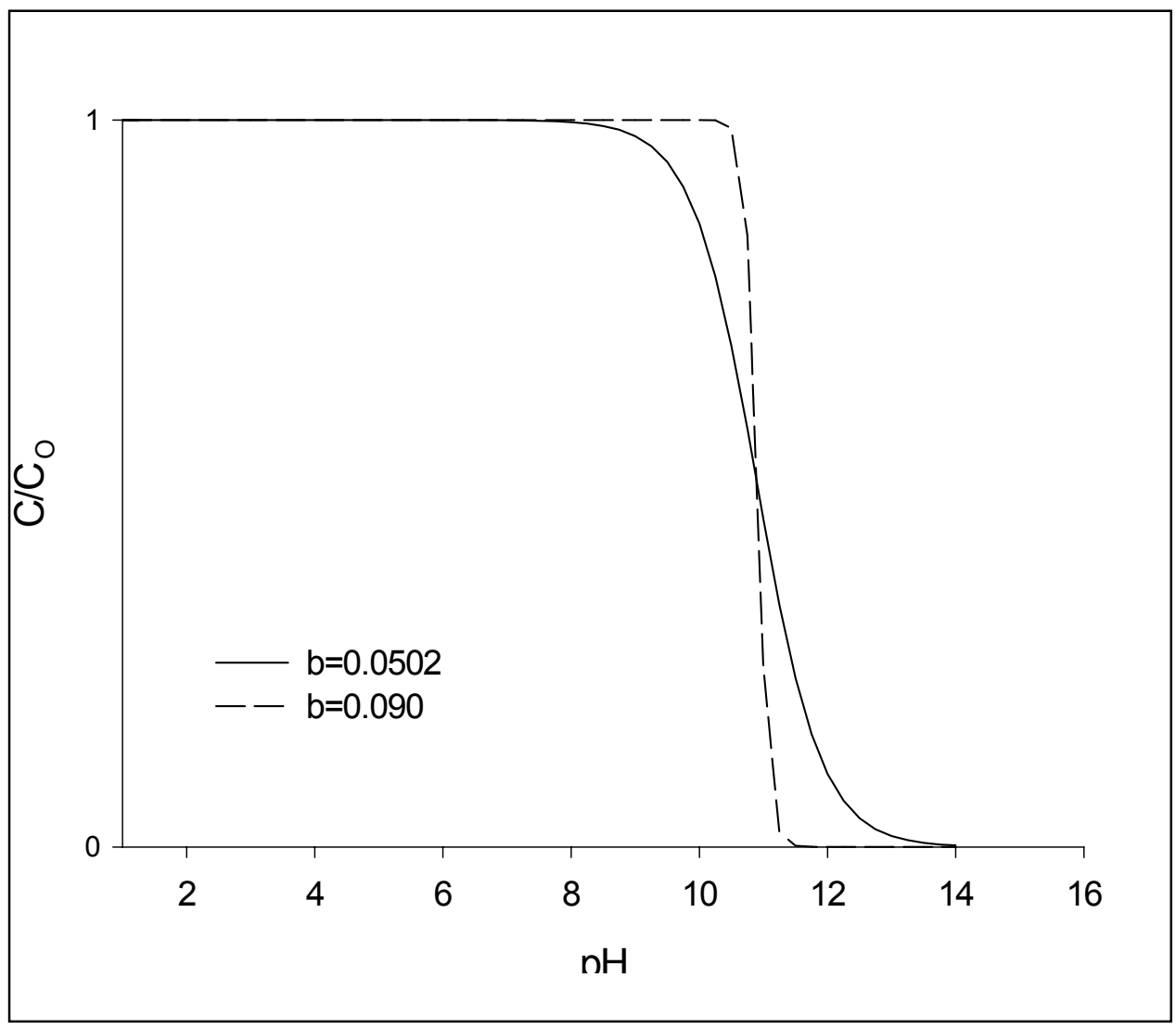

Figure 6. Parametric analysis of TNT removal model 


\section{Conclusions}

This study provided valuable information concerning the efficacy of hydroxide addition for remediating TNT-contaminated water. TNT was completely removed from aqueous solutions at $\mathrm{pHs}$ above 11.5 , and the addition of hydroxide to TNT solutions reduced toxicity.

Several questions will be addressed in further studies:

- What are products that are produced by the addition of hydroxide?

- Are other parameters (e.g., temperature, TNT concentration, counter-ion, etc.) significant in the removal of TNT?

- Will this method work for the remediation of TNT-contaminated soils? 


\section{References}

Agency for Toxic Substances and Disease Registry (ATSDR) (1995).

"Toxicological profiles for 2,4,6-trinitrotoluene (update)," Department of Health and Human Services, Public Health Service, Atlanta, GA.

Arienzo, M. (1999). "Decontamination of TNT-polluted water by fenton reagent," Proceedings of the Fifth International Symposium on Bioremediation of Nitroaromatic and Haloaromatic Compounds. B.C. Alleman and A. Leeson, ed., Battelle Press, Columbus, OH (7) 203-209.

Boopathy, R., Wilson, M., Montemagno, C. D., Manning, J. F., Jr., and Kulpa, C. F. (1994). "Biological transformation of 2,4,6-trinitrotoluene (TNT) by soil bacteria isolated from TNT-contaminated soil," Bioresource Technology 47, 19-24.

Bradley, P. M., and Chapelle, F. H. (1995). "Factors affecting microbial 2,4,6trinitrotoluene mineralization in contaminated soil," Environ. Sci. Technol. 29, 802-806.

Brannon, J. M., Price, C. B., and Hayes, C. (1998). "Abiotic transformation of TNT in montmorillonite and soil suspensions under reducing conditions," Chemosphere 36, 1453-1462.

Dillert, R., Brandt, M., Fornefett, I., Siebers, U., and Bahnemann, D. (1995). "Photocatalytic degradation of trinitrotoluene and other nitroaromatic compounds," Chemosphere 30, 2333-2341.

Dunnivant, F. M., and Schwarzenbach, R. P. (1992). "Reduction of substituted nitrobenzenes in aqueous solutions containing natural organic matter," Environmental Science and Technology 26, 2133-2141.

Emmrich, M. (1999). "Kinetics of the alkaline hydrolysis of 2,4,6-trinitrotoluene in aqueous solution and highly contaminated soils," Environmental Science and Technology 33, 3802-3805.

. (2001). "Kinetics of the alkaline hydrolysis of important nitroaromatic co-contaminants of 2,4,6-trinitrotoluene in highly contaminated soils," Environmental Science and Technology 35, 874-877.

Fernando, T., Bumpus, J. A., and Aust, S. D. (1990). "Biodegradation of TNT (2,4,6-trinitrotoluene) by Phanerochaete chrysosporium," Applied and Environmental Microbiology 56, 1666-1671. 
Funk, S. B., Roberts, D. J., Crawford, D. L., and Crawford, R. L. (1993). "Initialphase optimization for bioremediation of munition compound-contaminated soils," Applied and Environmental Microbiology 59, 2171-2177.

Harter, D. R. (1985). "The use and importance of nitroaromatic chemicals in the chemical industry," Toxicity of nitroaromatic compounds. D.E. Rickert, ed., Hemisphere Publishing Corp., New York, 1-14.

Heilmann, H., Wiesmann, U., and Stenstom, M. (1996). "Kinetics of alkaline hydrolysis of high explosives RDX and HMX in aqueous solution and adsorbed to activated carbon," Environmental Science and Technology 30, 1485-1492.

Jarvis, A. S., McFarland, V. A., and Honeycutt, M. E. (1998). "Cytotoxicity and mutagenicity of 2,4,6-trinitrotoluene and its metabolites," Ecotoxicological and Environmental Safety 39, 131.

Lang, P. S., Ching, W. K., Willberg, D. M., and Hoffman, M. R. (1998). "Oxidative degradation of 2,4,6-trinitrotoluene by ozone in an electrohydraulic discharge reactor," Environmental Science and Technology 32, 3142-3148.

McCormick, N. G., Feeherry, F. E., and Levinson, H. S. (1976). "Microbial transformation of 2,4,6-trinitrotoluene and other nitroaromatic compounds," Applied and Environmental Microbiology 31, 949-958.

Palazzo, A. J., and Leggett, D. C. (1986). "Effect and disposition of TNT in a terrestrial plant," Journal of Environmental Quality 15, 49-52.

Roberts, W. C., and Hartley, W. R. (1992). "Toxicological profiles of munitions and other environmental contaminants," Drinking Water Health Advisory: Munitions. W.C. Roberts and W.R. Hartley, ed., Lewis Publishers, Boca Raton, FL, 447-535.

Rosenblatt, D. H., Burrows, E. P., Mitchell, W. R., and Parmer, D. L. (1991). "Organic explosives and related compounds," The handbook of environmental chemistry. Volume 3, O. Hutzinger, ed., Springer-Verlag, Berlin, 196-234.

Saupe, A., Garvnes,H., and Heinze, L. (1997). "Alkaline hydrolysis of TNT and TNT in soil followed by thermal treatment of the hydrosylates," Chemosphere 36, 1725-1744.

Simini, M., Wentse, R. S., Checkai, R. T., Phillips, C. T., Chester, N. A., Major, M. A., and Amos, J. C. (1995). "Evaluation of soil toxicity at Joliet Army Ammunition Plant," Environmental Toxicology and Chemistry 14, 623-630.

Spiker, J. K., Crawford, D. L., and Crawford, R. L. (1992). "Influence of 2,4,6trinitrotoluene (TNT) concentration on the degradation of TNT in explosivecontaminated soils by the white rot fungus Phanerochaete chrysosporium," Applied and Environmental Microbiology 58, 3199-3202.

Tsia, T. (1991). "Biotreatment of red water - A hazardous waste stream from explosive manufacture with fungal systems," Hazardous Waste \& Hazardous Materials 8, 231-244. 
Urbanski, T. (1964). Chemistry and technology of explosives. McMillan, New York.

Won, W. D., DiSalvo, L. H., and Ng, J. (1976). "Toxicity and mutagenicity of 2,4,6-trinitrotoluene and its microbial metabolites," Applied and

Environmental Microbiology 31, 576-580. 


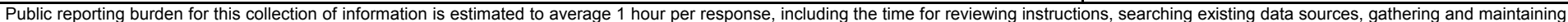

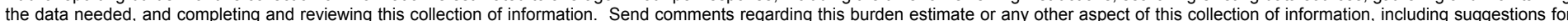

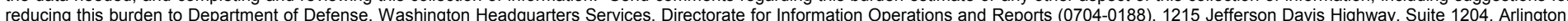

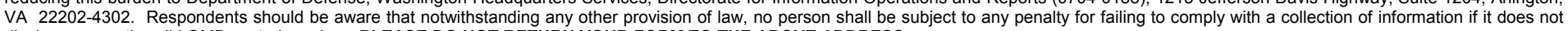
display a currently valid OMB control number. PLEASE DO NOT RETURN YOUR FORM TO THE ABOVE ADDRESS.
1. REPORT DATE (DD-MM-YYYY) 2. REPORT TYPE
3. DATES COVERED (From - To)

August 2001 Final report

\section{TITLE AND SUBTITLE}

Base-Induced 2,4,6-Trinitrotoluene Transformation, Titration Studies

5a. CONTRACT NUMBER

Base-Induced 2,4,6-Tinitrotoluene Transformation, Titration Studies

5b. GRANT NUMBER

5c. PROGRAM ELEMENT NUMBER

\section{AUTHOR(S)}

Lance D. Hansen, David D. Ringelberg, Deborah R. Felt, Jeffrey D. Davis

5d. PROJECT NUMBER

Lance D. Hansen, David D. Ringelberg, Deborah R. Felt, Jeffrey D. Davis

5e. TASK NUMBER

5f. WORK UNIT NUMBER

7. PERFORMING ORGANIZATION NAME(S) AND ADDRESS(ES)

8. PERFORMING ORGANIZATION REPORT

See reverse. NUMBER

ERDC TR-01-10

9. SPONSORING / MONITORING AGENCY NAME(S) AND ADDRESS(ES)

10. SPONSOR/MONITOR'S ACRONYM(S)

U.S. Army Corps of Engineers

Washington, DC 20314-1000

11. SPONSOR/MONITOR'S REPORT NUMBER(S)

\section{DISTRIBUTION / AVAILABILITY STATEMENT}

Approved for public release; distribution is unlimited.

\section{SUPPLEMENTARY NOTES}

\section{ABSTRACT}

The removal of 2,4,6-trinitrotoluene (TNT) from solution by the addition of a base, sodium hydroxide (NaOH), was examined. TNT solutions were titrated to determine the required hydroxide concentration for the removal of TNT from solutions to proceed. It was found that the $\mathrm{pH}$ required for removal of half the TNT was $10.9 \pm 0.18$ with an empirical coefficient of $0.16 \pm 0.11$. A parametric analysis was performed, and the model was determined not to be sensitive with respect to the empirical coefficient.

This study found a near-instant removal of TNT when the $\mathrm{pH}$ of the solution was increased above 11. Several unidentified compounds were formed sequentially. The sequence of these unidentified compounds appears to indicate an increase in their polarity. The addition of $\mathrm{NaOH}$ resulted in a reduction in the acute toxicity of TNT solutions based on Microtox ${ }^{\circledR}$ tests with Vibrio fischeri.

\begin{tabular}{|c|c|c|c|c|c|}
\hline \multicolumn{2}{|l|}{$\begin{array}{l}\text { 15. SUBJECT TERMS } \\
\text { 2,4,6-trinitrotoluene } \\
\text { Acute toxicity }\end{array}$} & $\begin{array}{l}\text { aline } \mathrm{pH} \\
\text { gradation } \\
\text { olosives }\end{array}$ & $\begin{array}{l}\text { Microtox } \\
\text { Munitions } \\
\text { Titration }\end{array}$ & \multicolumn{2}{|c|}{ UV spectra } \\
\hline \multicolumn{3}{|c|}{ 16. SECURITY CLASSIFICATION OF: } & $\begin{array}{l}\text { 17. LIMITATION } \\
\text { OF ABSTRACT }\end{array}$ & $\begin{array}{l}\text { 18. NUMBER } \\
\text { OF PAGES }\end{array}$ & $\begin{array}{l}\text { 19a. NAME OF RESPONSIBLE } \\
\text { PERSON }\end{array}$ \\
\hline $\begin{array}{l}\text { a. REPORT } \\
\text { UNCLASSIFIED }\end{array}$ & $\begin{array}{l}\text { b. ABSTRACT } \\
\text { UNCLASSIFIED }\end{array}$ & $\begin{array}{l}\text { c. THIS PAGE } \\
\text { UNCLASSIFIED }\end{array}$ & & 22 & $\begin{array}{l}\text { 19b. TELEPHONE NUMBER (include } \\
\text { area code) }\end{array}$ \\
\hline
\end{tabular}




\section{7. (Continued).}

U.S. Army Engineer Research and Development Center Environmental Laboratory

3909 Halls Ferry Road, Vicksburg, MS 39180-6199

U.S. Army Engineer Research and Development Center Cold Regions Research and Engineering Laboratory 72 Lyme Road, Hanover, NH 03755-1290

Applied Research Associates, Inc., Southern Division 112 Monument Place, Vicksburg, MS 39180 